\title{
Biofilm-Related Infections in Gram-Positive Bacteria and the Potential Role of the Long-Acting Agent Dalbavancin
}

\author{
Alessandra Oliva ${ }^{1}$, Stefania Stefani ${ }^{2}$, Mario Venditti ${ }^{1}$ and Enea Gino Di Domenico ${ }^{*}$ \\ 'Department of Public Health and Infectious Diseases, "La Sapienza" University of Rome, Rome, Italy, ${ }^{2}$ Laboratory \\ of Molecular Medical Microbiology and Antimicrobial Resistance Research (Mmarl), Department of Biomedical \\ and Biotechnological Sciences (Biometec), University of Catania, Catania, Italy, ${ }^{3}$ Microbiology and Virology, IRCCS San \\ Gallicano Institute, Rome, Italy
}

OPEN ACCESS

Edited by:

Daniel Pletzer,

University of Otago, New Zealand

Reviewed by:

Kristi L. Frank,

Uniformed Services University of the Health Sciences, United States

Durg Vijai Singh,

Central University of South Bihar, India

Rosalia Cavaliere,

University of Technology Sydney,

Australia

Oana Ciofu,

University of Copenhagen, Denmark

*Correspondence:

Enea Gino Di Domenico enea.didomenico@ifo.gov.it

Specialty section:

This article was submitted to Infectious Agents and Disease,

a section of the journal

Frontiers in Microbiology

Received: 29 July 2021 Accepted: 04 October 2021

Published: 22 October 2021

Citation:

Oliva A, Stefani S, Venditti M and Di Domenico EG (2021)

Biofilm-Related Infections

in Gram-Positive Bacteria and the Potential Role of the

Long-Acting Agent Dalbavancin.

Front. Microbiol. 12:749685.

doi: $10.3389 /$ fmicb.2021.749685
Infections caused by Gram-positive bacteria are a major public health problem due to their increasing resistance to antibiotics. Staphylococcus and Enterococcus species' resistance and pathogenicity are enhanced by their ability to form biofilm. The biofilm lifestyle represents a significant obstacle to treatment because bacterial cells become highly tolerant to a wide range of antimicrobial compounds normally effective against their planktonic forms. Thus, novel therapeutic strategies targeting biofilms are urgently needed. The lipoglycopeptide dalbavancin is a long-acting agent for treating acute bacterial skin and skin structure infections caused by a broad range of Gram-positive pathogens. Recent studies have shown promising activity of dalbavancin against Grampositive biofilms, including methicillin-resistant $S$. aureus (MRSA), methicillin-resistant S. epidermidis (MRSE), and vancomycin-susceptible enterococci. This review outlines the mechanisms regulating biofilm development in Staphylococcus and Enterococcus species and the clinical impact of biofilm-related infections. In addition, it discusses the clinical implications and potential therapeutic perspectives of the long-acting drug dalbavancin against biofilm-forming Gram-positive pathogens.

Keywords: biofilm, dalbavancin, Staphylococcus aureus, Gram-positive, skin, soft tissue infections

\section{INTRODUCTION}

Gram-positive bacteria are the most common human pathogens associated with medical devicerelated infections and skin and soft tissue infections (SSTI) (Del Pozo and Patel, 2009; Kaye et al., 2019). Staphylococcus aureus is the leading pathogen of catheters and prosthetic related infections or in chronic ulcers, while Enterococcus faecalis and Enterococcus faecium have become prominent etiological agents of nosocomial infections worldwide (Tong et al., 2015; Guzman Prieto et al., 2016). The global prevalence of drug-resistant strains of Gram-positive bacteria is increasing. Specifically, community- and hospital-acquired infections caused by Methicillinresistant $S$. aureus (MRSA) and vancomycin-resistant E. faecium (VRE) have become a serious concern (Huang et al., 2019).

The increasing prevalence of drug-resistant pathogens is further worsened by observing that pathogenic Gram-positive bacteria are particularly predisposed to form biofilms (Lebeaux et al., 2014). In hospital settings, biofilms are implicated in the pathogenesis of approximately $80 \%$ of chronic microbial infections or medical device-associated infections (MDI) 
(Römling and Balsalobre, 2012; Lebeaux et al., 2014). Furthermore, the biofilm lifestyle provides a broad and intrinsic multidrug tolerance allowing bacterial cells to survive a transient exposure to antibiotics without developing resistance (Di Domenico et al., 2019; Nguyen et al., 2020). Indeed, antibiotic resistance is genetically acquired by horizontal gene transfer or mutations, while the biofilm-related tolerance constitutes a multi-layered defense mechanism requiring slow-growing or non-dividing persister cells, poor antibiotic penetration, and adaptive stress responses (Lebeaux et al., 2014; Nguyen et al., 2020). Thus, the development of antibiotics with anti-biofilm activity represents a recognized need.

Dalbavancin is a semisynthetic lipoglycopeptide antibiotic structurally related to teicoplanin, with a long half-life and a unique dosage regimen, allowing for a single 1,500 $\mathrm{mg}$ dose or a two-dose (1,000 $\mathrm{mg}$ at day 1 and $500 \mathrm{mg}$ at day 8) regimen (Boucher et al., 2014; Dunne et al., 2016). This antibiotic has a broad spectrum of action against Gram-positive cocci, including MRSA, and is approved for the treatment of SSTI (ArrietaLoitegui et al., 2020). There is a growing amount of evidence that dalbavancin could be useful in other invasive Grampositive infections that need prolonged intravenous treatments, including osteomyelitis, prosthetic joint infections (PJI), infective endocarditis, and catheter-related bacteremia (David et al., 2017). In addition, recent studies conducted in vitro and on human and animal models demonstrated that dalbavancin might also be effective against bacterial biofilms produced by staphylococci and enterococci (Knafl et al., 2017; Neudorfer et al., 2018; Silva et al., 2020; Žiemytè et al., 2020).

This review highlights the basic mechanisms regulating biofilm development in Gram-positive bacteria in the most clinically relevant infections along with the general principles of antimicrobial treatment of biofilm-associated infections. In addition, this review summarizes the current understanding and potential therapeutic activity of dalbavancin against in vitro and in vivo models of biofilm-related infections caused by Grampositive bacteria.

\section{Role of Biofilms in Gram-Positive Infections}

Immediately after placing a medical device into the patient's body, biomaterials are rapidly coated with a conditioning film, a layer of the host organic elements absorbed onto the substratum. This conditioning layer generally provides a favorable substrate for bacteria to attach to the implant (Neoh et al., 2017). The adhesion of planktonic cells to the implant surface is the first step toward biofilm formation (Berne et al., 2018). In staphylococci, the adhesion to human tissue or indwelling medical devices is regulated by a large variety of surfaceanchored proteins that bind to host tissues and cells, referred to as microbial surface components recognizing adhesive matrix molecules (MSCRAMMs) (Foster, 2019). These proteins are also present on Enterococcus faecalis and Enterococcus faecium and are required in the first step of human tissues colonization (Sava et al., 2010). There are two families of MSCRAMM molecules related to clumping factor A (ClfA) of S. aureus and serine-aspartate repeat protein $\mathrm{G}$ ( $\mathrm{SdrG}$ ) of $S$. epidermidis and another group referred to as the collagen-binding protein of $S$. aureus (the Cna family) (Foster, 2019). A single MSCRAMM protein performs several functions as binding to a diverse array of host ligands. Those molecules allow for unspecific attachment mediated by hydrophobic, electrostatic hydrogen-bonding, and van der Waals interactions with complementary receptors present in the conditioning film (Katsikogianni and Missirlis, 2004). In the early stages of biofilm growth, adherent cells are loosely associated with a surface. This is called the reversible attachment stage (Berne et al., 2018). During this phase complete eradication of the MDI can be achieved by the careful surgical debridement of tissue and bone marrow, and local antimicrobial therapy to eliminate planktonic bacteria (Høiby et al., 2015; Masters et al., 2019; da Silva et al., 2021). Indeed, in the early onset of a MDI, a major role is played by the potent virulence response of the infectious pathogen, which causes tissue destruction that may sometimes culminate in fulminant infections (Zimmerli et al., 2004; Masters et al., 2019; Seebach and Kubatzky, 2019). After the initial bacterial attachment to a surface, intracellular accumulation and biofilm maturation occur (Nguyen et al., 2020). The presence of a mature biofilm in either the local tissue or the implant requires more radical procedures (i.e., the complete removal of the implant) and prolonged therapies, often by the intravenous route, to remove the infection (Masters et al., 2019). During biofilm maturation, individual cells enter the irreversible attachment stage, and the bacterial cells produce the biofilm matrix. The irreversible attachment can be modulated by environmental factors such as $\mathrm{pH}$, hydrodynamics, nutrient availability, temperature, osmolarity, oxygen, or other host factors (Palmer et al., 2007; Lister and Horswill, 2014; Berne et al., 2018). At this stage, mature biofilms are highly tolerant to host immune defenses, stresses, starvation, dehydration and cannot be eradicated by antibiotic treatments alone (Masters et al., 2019). In staphylococci and enterococci, similar factors contribute to the biofilm matrix composition including polysaccharides, proteins, teichoic and lipoteichoic acids, and extracellular DNA (eDNA) (Ch'ng et al., 2019; Karygianni et al., 2020). In staphylococci, the polysaccharide intercellular adhesin (PIA), also known as poly-N-acetyl glucosamine (PNAG), according to the chemical composition (Nguyen et al., 2020) is an important adhesive molecule during biofilm formation. The biosynthesis and accumulation of PIA on the bacterial surface are regulated by the intercellular adhesion (ica) gene locus products, including the icaA, icaD, icaB, and icaC genes. Although PIA plays a central role in staphylococcal biofilm, several studies have demonstrated that biofilm formation can be accomplished by $S$. epidermidis and $S$. aureus isolates in the absence of the ica operon by a PIA-independent mechanism (Otto, 2018; Nguyen et al., 2020). This process is particularly relevant to methicillin-resistant $S$. aureus (MRSA) strains where biofilm formation depends mainly on proteins rather than polysaccharides (McCarthy et al., 2015). In E. faecalis, the dltABCD operon is required to obtain d-alanine esters of lipoteichoic acids, which is an essential constituent of the Gram-positive bacterial cell wall (Ch'ng et al., 2019). A deletion mutant of the dltA gene in E. faecalis produces significantly less biofilm in vitro, reduced 
adherence to epithelial cells, and increased susceptibility to cationic antimicrobial peptides. These results suggest a potential contribution of d-alanine of lipoteichoic acids in the pathogenesis of E. faecalis (Fabretti et al., 2006).

A mature biofilm is typically associated with chronic infections, which persist despite apparently adequate antibiotic treatment. Indeed, chronic infections may have a silent course for several months, perhaps years before the clinical symptoms appear. Chronic infections are mainly characterized by a local and persistent inflammatory response surrounding the biofilm. The infection's signs and symptoms may vary depending on the organ's function or implanted device (Høiby et al., 2015). An infection frequently characterized by less dramatic outcomes and persistent pain as the only manifestation (together with elevated C-reactive protein levels, although not always present) is a PJI (Masters et al., 2019). The majority of PJIs are thought to occur during surgery, due to the incidental introduction of skin commensals into the surgical site or onto the newly implanted device (Zimmerli et al., 2004). In a late PJI, biofilm cells remain quiescent and localized in the implant surface and the surrounding tissues. However, bacterial cells may continuously release from the biofilm by a dispersal process which may contribute to bacteremia and sepsis or disseminate to other implants within the body (Lister and Horswill, 2014). Dispersion of S. aureus from the biofilm into the environment is an active mechanism mediated by the production of extracellular enzymes or surfactants controlled by the activity of the accessory gene regulator ( $a g r$ ) system (Otto, 2018). As a quorum-sensing (QS) communication system, the agr locus regulates more than 70 genes in $S$. aureus, 23 of which are directly involved in its virulence (Otto, 2018). Specifically, the agr locus controls the expression of surface binding proteins, toxins, proteases, lipases, nucleases. The QS response also regulates matrix modification and dispersion in E. faecalis (Ch'ng et al., 2019). The Fsr (Enterococcus faecalis sensor regulator) QS system is a signal transduction system that controls the extracellular metalloprotease, gelatinase (GelE) (Ch'ng et al., 2019). Mutations in the $f s r$ system or gelE revealed that gelatinase has an important role in E. faecalis biofilm formation and increased virulence in different animal infection models (Hancock and Perego, 2004; Sava et al., 2010). The released cell subpopulation, spreading from the original colony, is typically more virulent, with altered metabolic activity and antimicrobial susceptibilities than their biofilm and planktonic counterparts. Thus, the dispersed cell may result in more severe and persistent infections (Rumbaugh and Sauer, 2020).

\section{Clinical-Therapeutic Approach to Biofilm-Related Infections General Principles}

As a general concept, the clinical management of biofilm-related infections requires the complete removal of the infected device with surgical debridement followed by implant replacement along with targeted antibiotics against biofilms and planktonic cells (Høiby et al., 2015; Agarwal et al., 2020). Indeed, using antimicrobials with activity against biofilm positively influences the outcome, irrespective of the type of surgery performed (Gellert et al., 2020; Köder et al., 2020).

The purpose of surgery is to remove (i) the foreign body along with the surrounding patchy distributed biofilm, (ii) the infecting sessile germs, and (iii) the devitalized tissue, if any (Høiby et al., 2015; Izakovicova et al., 2019; Agarwal et al., 2020). At this stage, it is essential to put in place a targeted therapy (Table 1) to minimize the bacterial adhesion ability and prevent new biofilm formation by the residual microbial burden. One exception to the complete removal of a foreign body is the presence of early biofilm (i.e., implant infection within 3 weeks from implant placement or during concomitant bacteremia with further involvement of the implant). In this case, surgical debridement and the possibility of keeping the essential parts of the foreign body are recommended.

The so-called Debridement, Antibiotics, and Implant Retention (DAIR) approach is considered the optimal choice, showing a high clinical cure rate, especially in PJIs. During this procedure, radical debridement of all necrotic tissues, synovectomy, excision of sinus tracts and thorough irrigation with copious volumes of sterile saline is performed, combined with replacement of mobile, easily exchangeable prosthetic parts and targeted therapy for 6-12 weeks with the antibiotics listed in Table 1 (Høiby et al., 2015; Izakovicova et al., 2019; Agarwal et al., 2020). However, individual patients may not be candidates for any device removal, i.e., subjects with an unacceptably high risk for mortality due to surgery, subjects with a limited life expectancy, or those refusing device explanation (Peacock et al., 2018).

In these cases, alternative options such as conservative management with device retention and long-term suppressive antimicrobial therapy may be considered (Segreti et al., 1998; Pavoni et al., 2002, 2004; Peacock et al., 2018; Izakovicova et al., 2019).

\section{Antimicrobial Treatment}

Biofilm-embedded bacteria are up to 100-1,000 times less susceptible to antibiotics than their planktonic counterpart (Sharma et al., 2019). In this context, conventional in vitro susceptibility testing methods are unsuitable; therefore, when choosing antimicrobials, the key step is to consider their antibiofilm activity. Table $\mathbf{1}$ attempts to list the characteristics of the most common antibiotics with efficacy against biofilm and summarizes the current knowledge on the two main steps of antimicrobial activity in this setting, i.e., diffusion through the biofilm matrix and activity against sessile bacterial cells (Ciofu et al., 2017; Izakovicova et al., 2019; Abad et al., 2020). There is also a third, preliminary stage, which has been described for rifampicin, minocycline, linezolid, macrolides, colistin, and dalbavancin: the ability to prevent/impair bacterial adhesion on inert surfaces and subsequent biofilm deposition (ParraRuiz et al., 2012; Ciofu et al., 2017; Albano et al., 2019; Izakovicova et al., 2019; Di Pilato et al., 2020). The antistaphylococcal biofilm agent par excellence is rifampicin, followed by two drugs with similar potentials, the long-acting agents rifabutin and rifapentine. Nevertheless, rifampicin should not be used as monotherapy due to the risk of rapid development 
TABLE 1 | Activity of different antibiotics against biofilm-growing Gram-positive bacteria.

\begin{tabular}{|c|c|c|c|}
\hline Author, year & Antimicrobial agent & Penetration into the biofilm matrix & Activity against sessile cells \\
\hline Landini et al. (2015) and Lázaro-Díez et al. (2016) & Beta-lactams & Reduced to a varying degree & None \\
\hline Jo and Ahn (2016) and Di Domenico et al. (2019) & Quinolones & Yes & Active \\
\hline Henry-Stanley et al. (2014) and Di Domenico et al. (2019) & Aminoglycosides & Reduced & Reduced \\
\hline Darouiche et al. (1999) & Minocycline & Yes & Active \\
\hline Tang et al. (2013) and Di Domenico et al. (2019) & Rifampicin & Yes & Active \\
\hline Darouiche et al. (1994) and Doroshenko et al. (2014) & Vancomycin & Severely reduced & Not known \\
\hline Leite et al. (2011) and Parra-Ruiz et al. (2012) & Daptomycin & Yes & Not known \\
\hline Parra-Ruiz et al. (2012) & Linezolid & Yes & Reduced \\
\hline Tang et al. (2012) & Fosfomycin & Yes & Active \\
\hline Silva et al. (2020) and Žiemytẻ et al. (2020) & Dalbavancin & Reduced & Not known \\
\hline Landini et al. (2015) and Lázaro-Díez et al. (2016) & Beta-lactams & Reduced to a varying degree & None \\
\hline Jo and Ahn (2016) and Di Domenico et al. (2019) & Quinolones & Yes & Active \\
\hline Henry-Stanley et al. (2014) and Di Domenico et al. (2019) & Aminoglycosides & Reduced & Reduced \\
\hline Darouiche et al. (1999) & Minocycline & Yes & Active \\
\hline Tang et al. (2013) and Di Domenico et al. (2019) & Rifampicin & Yes & Active \\
\hline Darouiche et al. (1994) and Doroshenko et al. (2014) & Vancomycin & Severely reduced & Reduced \\
\hline Leite et al. (2011) and Parra-Ruiz et al. (2012) & Daptomycin & Yes & Not known \\
\hline Parra-Ruiz et al. (2012) & Linezolid & Yes & Reduced \\
\hline Tang et al. (2012); Mihailescu et al. (2014), and Oliva et al. (2014) & Fosfomycin & Yes & Active \\
\hline Silva et al. (2020) and Žiemytè et al. (2020) & Dalbavancin & Reduced & Not known \\
\hline
\end{tabular}

of in vivo resistance (Høiby et al., 2015; Ciofu et al., 2017; Izakovicova et al., 2019). Therefore, the association with other anti-staphylococcal drugs is recommended not only on account of their frequent synergistic activity but also to minimize the development of resistance. To this end, since the emergence of rifampicin resistance is proportional to the bacterial burden, there is also a recommendation to initiate the antimicrobial therapy with partner antibiotics such as oxacillin, daptomycin, or dalbavancin, to reduce the bacterial load, and then after 3-5 days add rifampicin in association (Høiby et al., 2015; Izakovicova et al., 2019). In in vitro and animal models, rifampicin showed activity also against biofilm formed by Cutibacterium acnes (Furustrand Tafin et al., 2012). However, in a recent study on PJI caused by C. acnes, rifampicin therapy did not seem to improve outcomes, suggesting the need for additional studies on humans (Vilchez et al., 2021).

The choice of antibiotics against enterococcal biofilms is limited, and, with this regard, no activity of rifampicin has been shown (Oliva et al., 2014). On the other hand, the "old" antibiotic fosfomycin, which has been recently rediscovered mostly to treat multidrug-resistant bacteria, showed high activity against both staphylococcal and enterocococcal biofilms (Mihailescu et al., 2014; Oliva et al., 2014; Zheng et al., 2019). Nevertheless, similarly to rifampicin, fosfomycin monotherapy allows the rapid selection of resistant variants, and therefore it should always be used in combination. As an alternative to the traditional approach combining surgery plus antibiotics, chronic suppressive therapy is selected when a patient's general conditions or the technical difficulties connected with the surgery are such as to preclude both removal and replacement of the foreign body and debridement. After initial targeted therapy with antibiotics by the intravenous route, the subsequent step is to keep the infection "silent" by administering a prolonged oral therapy for an indefinite duration, including, amongst others, the use of minocycline and/or trimethoprim/sulfamethoxazole and/or fluoroquinolones, according to the causative agent and the patient's characteristics (Pavoni et al., 2004; Izakovicova et al., 2019; Qu et al., 2019). This approach is mainly described in orthopedic implant infections and more rarely in the management of cardiac implant or vascular graft infections (Segreti et al., 1998; Pavoni et al., 2002, 2004; Peacock et al., 2018; Izakovicova et al., 2019; Blomström-Lundqvist et al., 2020). However, some patients do not even tolerate this approach, mainly due to side effects during suppressive therapy (Segreti et al., 1998; Spaziante et al., 2019). In such cases, an alternative option, currently under study, is the use of dalbavancin for a prolonged period with intravenous administrations at intervals of up to 12 weeks apart, driven by the determination of the serum bactericidal assay, as recently described (Spaziante et al., 2019). Another alternative strategy aimed to retain in place the foreign body is represented by intra-lock therapy, which refers to the treatment of catheter-related bloodstream infections and may be considered only if there are absolute contraindications to catheter removal. Antibiotics for the lock therapy are at high concentrations (up to 100-1,000 times higher than the MIC). They may include aminoglycosides, betalactams, fluoroquinolones, glycopeptides, daptomycin, linezolid, minocycline, and tigecycline, with the largest evidence for gentamicin and vancomycin (Justo and Bookstaver, 2014). However, when selecting antimicrobials for the intra-lock therapy, additional characteristics such as stability, compatibility with anticoagulants, selection of resistance, rate of systemic 
TABLE 2 | Dalbavancin in the treatment of bone and joint infections: an analysis of the literature.

\begin{tabular}{|c|c|c|c|c|}
\hline Author, year & Study design, cases & $\begin{array}{l}\text { Dose }^{\circ} \text { and duration of dalbavancin } \\
\text { therapy }\end{array}$ & Clinical success & $\begin{array}{l}\text { Adverse } \\
\text { events }\end{array}$ \\
\hline $\begin{array}{l}\text { Almangour et al. } \\
(2017)\end{array}$ & $\begin{array}{l}\text { Case report, spondylodiscitis caused } \\
\text { by MRSA }\end{array}$ & $\begin{array}{l}1 \times 1,000 \mathrm{mg} \text { loading dose, then } \\
500 \mathrm{mg} / \text { week } \times 6 \text { times }\end{array}$ & Yes, at the end of therapy (follow up: no) & None \\
\hline Bouza et al. (2018) & Retrospective: 12 OM, 5 PJI & $\begin{array}{l}\text { Varying: mean of } 4 \text { doses (range 1-9), } \\
\text { 3-week duration (range 1-24) }\end{array}$ & $\begin{array}{l}\text { 92\% for OM, 80\% for PJI (follow up: } 1 \\
\text { month) }\end{array}$ & $13 \%$, mild \\
\hline Rappo et al. (2018) & $\begin{array}{l}\text { Prospective randomized; Dal: } 70 \text { vs. ST: } \\
\text { 10; } 80 \text { OM }\end{array}$ & $1 \mathrm{gr}$ IV on days 1 and 8 & $96 \%$ dal vs. $88 \%$ ST & None for dal \\
\hline $\begin{array}{l}\text { Tobudic et al. } \\
\text { (2018) }\end{array}$ & $\begin{array}{l}\text { Retrospective: } 20 \text { OM, } 8 \text { PJl; } 14 \text { SPD, } 4 \\
\text { SAR }\end{array}$ & $\begin{array}{l}\text { Varying: median duration of } 8 \text { weeks } \\
\text { (range 4-32) }\end{array}$ & $\begin{array}{l}60 \% \text { for OM, 38\% for PJl; } 50 \% \text { for SPD; } \\
100 \% \text { for SAR (follow up: } 6 \text { months) }\end{array}$ & $2.8 \%$, mild \\
\hline $\begin{array}{l}\text { Wunsch et al. } \\
\text { (2019) }\end{array}$ & Retrospective: 30 OM, 32 PJI & Varying: mean of 3 doses (range 1-32) & $\begin{array}{l}89 \% \text { for OM, } 91 \% \text { for PJl (at the end of } \\
\text { therapy, no follow up) }\end{array}$ & $3 \%$, mild \\
\hline $\begin{array}{l}\text { Bryson-Cahn et al. } \\
\text { (2019) }\end{array}$ & Retrospective: 7 OM & Varying: median of 1 dose (range 1-5) & 71\% (follow up: 1 year) & None \\
\hline Morata et al. (2019) & Retrospective: 19 OM/SPD, 26 PJI & Varying: median of 5 doses (IQR 3-8) & $\begin{array}{l}90 \% \text { for OM/SPD; } 65 \% \text { for PJI (follow up: } \\
6 \text { months) }\end{array}$ & $11 \%$, mild \\
\hline $\begin{array}{l}\text { Almangour et al. } \\
\text { (2019) }\end{array}$ & Retrospective: 29 OM/SPD, 2 PJI & $\begin{array}{l}\text { Varying: median of } 3 \text { doses (range } \\
1-14 \text { ) }\end{array}$ & $\begin{array}{l}93 \% \text { for OM/SPD, 100\% for PJI (follow up: } \\
3 \text { months) }\end{array}$ & None \\
\hline $\begin{array}{l}\text { Bartoletti et al. } \\
\text { (2019) }\end{array}$ & $\begin{array}{l}\text { Retrospective: } 15 \text { sternal OM } \\
\text { post-cardiac surgery }\end{array}$ & Varying: median of 4 doses & $\begin{array}{l}\text { 93\% (follow up: } 6 \text { months) (follow up: } 1 \\
\text { month) }\end{array}$ & None \\
\hline Bork et al. (2019) & Retrospective: 11 OM, 1 PJI & Varying: median of 3 doses (IQR 4.5) & $55 \%$ for OM; $100 \%$ for IPA & 13\%, mild \\
\hline Streifel et al. (2019) & Retrospective: $11 \mathrm{OM}$ & Varying: mean of 2.7 weeks & 76\% (follow up: 1 month) & $8 \%$, mild \\
\hline $\begin{array}{l}\text { Almangour and } \\
\text { Alhifany (2020) }\end{array}$ & $\begin{array}{l}\text { Retrospective case-control Dal: } 11 \mathrm{OM} \\
\text { vs. ST } 11 \mathrm{OM}\end{array}$ & Varying: mean of 2 doses & $100 \%$ in both arms & None \\
\hline Loupa et al. (2020) & $\begin{array}{l}\text { Case report, diabetic foot OM caused } \\
\text { by multi-drug resistant Enterococcus } \\
\text { faecium }\end{array}$ & $\begin{array}{l}2 \times 1,500 \mathrm{mg} \text { in combination with oral } \\
\text { lin and intravenous tig }\end{array}$ & Yes, at the end of the therapy & None \\
\hline Veve et al. (2020) & $\begin{array}{l}\text { Retrospective: osteoarticular infection } \\
\text { (OM, PJl, septic arthritis), infective } \\
\text { endocarditis or other bloodstream } \\
\text { infection } 70 \text { dal and } 145 \text { ST }\end{array}$ & $\begin{array}{l}\text { Varying: the most frequent ( } 34 \%) \text { was } \\
1,500 \text { mg for two doses } 1 \text { week apart }\end{array}$ & $\begin{array}{l}\text { Lower rate of 90-day infection-related } \\
\text { readmission in dal treated (17\%) vs. ST } \\
(28 \%)\end{array}$ & $\begin{array}{l}3 \% \text { dal vs. } 14 \% \\
\text { ST }\end{array}$ \\
\hline Matt et al. (2021) & Retrospective: 17 PJI & $\begin{array}{l}\text { Varying: the most frequent ( } 8 \text { patients) } \\
\text { was } 1,500 \text { mg at Day } 1 \text { and } 1,500 \text { mg } \\
\text { at Day } 7\end{array}$ & $47 \%$ after a median follow-up of 299 days & Not specified \\
\hline $\begin{array}{l}\text { Navarro-Jiménez } \\
\text { et al. (2021) }\end{array}$ & $\begin{array}{l}\text { Retrospective, descriptive study: } 23 \\
\text { OM (diabetic foot infection) }\end{array}$ & $\begin{array}{l}\text { Varying: the most frequent ( } 8 \text { patients) } \\
\text { was } 1,000 \text { mg followed by } 500 \text { mg } \\
\text { weekly for } 5 \text { weeks }\end{array}$ & $87 \%$ at 90 days after completion of dal & $13 \%$, mild \\
\hline
\end{tabular}

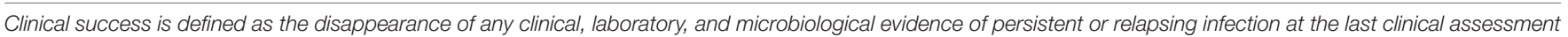

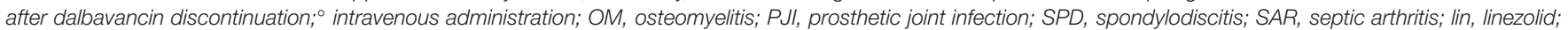
dal, dalbavancin; tig, tigecycline; ST, standard therapy.

absorption with possible consequent side effects, and costeffectiveness should be considered (Justo and Bookstaver, 2014).

Overall, foreign body infections are associated with increasingly complex implications as the number and variety of implantable devices grow, especially in subjects with critical conditions or peculiar psychological profiles (i.e., refusal of surgery). Therefore, clinicians are often called upon to "invent" new therapeutic strategies (Pavoni et al., 2002).

It should also be taken into account that the traditional antimicrobial strategy toward implant-associated infections requires prolonged antimicrobial administration, largely by intravenous route. Consequently, multiple or prolonged hospitalizations may be required, therefore exposing patients, especially those with several comorbidities or immune suppression, to the risk of acquiring nosocomial and multidrugresistant microorganisms (Buke et al., 2007). This is especially true if elderly patients are considered and if additional invasive procedures are necessary (i.e., central venous access placement for antibiotic administration). Therefore, alternative strategies such as the Outpatient Parenteral Antibiotic Therapy (OPAT) and the long-acting dalbavancin are increasingly adopted to overcome these drawbacks.

\section{Potential Role of Dalbavancin in the Treatment of Gram-Positive Biofilms}

Dalbavancin currently represents the ultralong acting agent with the most extensive experience of use (Baldoni et al., 2013). Specifically, dalbavancin is a novel semisynthetic antimicrobial agent belonging to the second-generation lipoglycopeptides family approved by the FDA and the EMA for the treatment of acute bacterial skin and skin structure infections (ABSSSI). Dalbavancin inhibits the late stages of peptidoglycan synthesis, interrupting bacterial 
TABLE 3 | Dalbavancin in the treatment of infective endocarditis: an analysis of the literature.

\begin{tabular}{|c|c|c|c|c|c|}
\hline Author, year & Study design, cases & Prior therapy & $\begin{array}{l}\text { Dose }^{\circ} \text { and duration of } \\
\text { dalbavancin therapy }\end{array}$ & Clinical response* & Adverse events \\
\hline $\begin{array}{l}\text { Steele et al. } \\
(2018)\end{array}$ & $\begin{array}{l}1 \text { NVE-rt in pregnancy, } \\
\text { MRSA }\end{array}$ & Van 5 dd, dap 27 dd & $\begin{array}{l}1 \times 1,000 \mathrm{mg} \text { loading } \\
\text { dose, then } 500 \mathrm{mg} / \text { week } \times \\
3 \text { times }\end{array}$ & $\begin{array}{l}\text { Failure; success with } \\
\text { cef }+ \text { dap }\end{array}$ & $\begin{array}{l}\text { The emergence of } \\
\text { van-intermediate/tel } \\
\text { non-susceptible MRSA } \\
\text { during therapy with dal }\end{array}$ \\
\hline $\begin{array}{l}\text { Tobudic et al. } \\
\text { (2018) }\end{array}$ & $\begin{array}{l}\text { Retrospective: } 27 \\
\text { cases of endocarditis: } \\
59 \% \text { NVE, 22\% PVE, } \\
\text { 19\% PME; surgical } \\
\text { therapy: } 80 \% \text { in } \\
\text { PVE/PME. }\end{array}$ & $\begin{array}{l}\text { 89\% prior therapies, with dal } \\
\text { initiated after bacteremia } \\
\text { clearance }\end{array}$ & $\begin{array}{l}33 \%: 1,000 \text { mg load, then } \\
500 \text { mg/week; } 66 \% \\
1,500 \text { mg load, then } \\
\text { 1,000 mg/week. Mean } \\
\text { duration: } 42 \text { dd }\end{array}$ & 92\% clinical success & $\begin{array}{l}1 \text { nausea; } 1 \text { increased } \\
\text { serum creatinine }\end{array}$ \\
\hline $\begin{array}{l}\text { Kussmann } \\
\text { et al. (2018) }\end{array}$ & $\begin{array}{l}1 \mathrm{PME}, \mathrm{MSSA} \text { (PM not } \\
\text { removable?) }\end{array}$ & 5 prior therapies for over 1 year & $\begin{array}{l}\text { Doses and dosing intervals } \\
\text { not specified; duration of } \\
\text { about } 30 \text { weeks }\end{array}$ & $\begin{array}{l}\text { Not reported; isolation of } \\
\text { strains not sensitive to dal } \\
\text { from blood culture and } \\
\text { explanted PM }\end{array}$ & $\begin{array}{l}\text { Resistance to dal, case of } \\
\text { PM not explanted }\end{array}$ \\
\hline $\begin{array}{l}\text { Dinh et al. } \\
\text { (2019) }\end{array}$ & $\begin{array}{l}\text { Retrospective: } 9 \text { NVE, } \\
10 \text { PVE }\end{array}$ & $\begin{array}{l}\text { 99\% prior therapies with a } \\
\text { median duration (IQR) of } 23 \mathrm{dd} \text {; } \\
\text { dal initiated after } 2.5 \text { lines of } \\
\text { therapy (mean) }\end{array}$ & $\begin{array}{l}53 \%: 1 \text { or } 2 \text { doses of } \\
1,500 \text { mg weekly }\end{array}$ & $73 \%$ clinical success & $\begin{array}{l}\text { Stop dal: }=0 \% ; 2 \\
\text { hypersensitivity reactions }{ }^{\circ}\end{array}$ \\
\hline $\begin{array}{l}\text { Morrisette et al. } \\
(2019)\end{array}$ & Retrospective: 5 NVE & $\begin{array}{l}91 \% \text { prior therapies with a } \\
\text { mean duration of } 27 \mathrm{dd} ; 30 \% \\
\text { combo } \wedge\end{array}$ & $\begin{array}{l}60 \% \text { dal } 1 \times 1,500 \mathrm{mg} \\
\text { dose at end of therapy }\end{array}$ & $100 \%$ clinical success & $\begin{array}{l}\text { Infusion reactions, phlebitis } \\
\text { at the infusion site }\end{array}$ \\
\hline $\begin{array}{l}\text { Bryson-Cahn } \\
\text { et al. (2019) }\end{array}$ & $\begin{array}{l}\text { Retrospective: } 9 \\
\text { NVE-rt, OMSSA, } 7 \\
\text { MRSA }\end{array}$ & $\begin{array}{l}100 \% \text { prior therapies; } \\
\text { bacteremia clearance before } \\
\text { initiating dal }\end{array}$ & $\begin{array}{l}6 \text { cases of } 1 \times 1,000 \mathrm{mg} \\
\text { dose; } 3 \text { cases of two doses } \\
(1,000 \mathrm{mg} \text { then } 500 \mathrm{mg} \\
\text { after } 7 \mathrm{dd})\end{array}$ & $\begin{array}{l}\text { 5/9 clinical success; } 4 / 9 \\
\text { discharged patients } \\
\text { improved but were lost at } \\
\text { follow-up }\end{array}$ & None \\
\hline $\begin{array}{l}\text { Wunsch et al. } \\
\text { (2019) }\end{array}$ & $\begin{array}{l}\text { Retrospective: } 15 \text { NVE, } \\
6 \text { PVE, } 4 \text { PME; } 3 \text { cases } \\
\text { of associated } \\
\text { spondylodiscitis }\end{array}$ & $\begin{array}{l}100 \text { prior therapies; } 60 \% \\
\text { combo }\end{array}$ & $\begin{array}{l}9 \text { cases of } 1 \times 1,500 \mathrm{mg} \\
\text { dose; } 8 \text { cases of multiple } \\
\text { weekly doses of } 500 \mathrm{mg} \text {, } \\
\text { preceded by a loading } \\
\text { dose of } 1,000 \mathrm{mg}\end{array}$ & $\begin{array}{l}\text { 89\% clinical success; } 1 \\
\text { death during therapy }\end{array}$ & $\begin{array}{l}1 \text { hypertension during } \\
\text { infusion; } 1 \text { muscle } \\
\text { weakness; } 1 \text { vertigo }\end{array}$ \\
\hline $\begin{array}{l}\text { Hidalgo-Tenorio } \\
\text { et al., } 2019\end{array}$ & $\begin{array}{l}\text { Retrospective: } 83 \\
\text { (59.04\% bloodstream } \\
\text { infection, } 49.04 \% \\
\text { infective endocarditis } \\
\text { (44.04\% PVE, 32.4\% } \\
\text { NVE, 23.5\% } \\
\text { pacemaker lead) }\end{array}$ & $\begin{array}{l}\text { Dap }(68.6 \%), \text { cex }(28.6 \%), \text { van } \\
(22.9 \%), \operatorname{lin}(8.6 \%)\end{array}$ & $\begin{array}{l}\text { Varying: the most frequent } \\
\text { (12 patients) was } 1,500 \mathrm{mg} \\
\text { (1 day) }\end{array}$ & $\begin{array}{l}\text { In hospital clinical cure in all } \\
\text { patients; at } 12 \text { months, } \\
2.9 \% \text { therapeutic failure }\end{array}$ & $4.8 \%$, mild \\
\hline $\begin{array}{l}\text { Spaziante et al. } \\
(2019)\end{array}$ & $\begin{array}{l}1 \mathrm{PVE} \\
\text { MRSE + S. mitis, } \\
\text { considered to be } \\
\text { inoperable }\end{array}$ & $\begin{array}{l}\text { Pip/taz + dap, then cef }+ \text { dap. } \\
\text { Dal initiated after bacteremia } \\
\text { clearance }\end{array}$ & $\begin{array}{l}1,500 \mathrm{mg} \text { on days } 1,7,42, \\
112,189,255^{\prime \prime}, 315^{\prime \prime}, \\
370^{\prime \prime} \text { (the frequency of } \\
\text { infusions was guided by } \\
\text { SBP-values } \leq 1: 8 \text { ) }\end{array}$ & $\begin{array}{l}\text { Net clinical and PET/CT } \\
\text { improvement, no relapse } \\
\text { after more than } 1 \text { year from } \\
\text { dal discontinuation } \$\end{array}$ & None \\
\hline $\begin{array}{l}\text { Veve et al. } \\
(2020)\end{array}$ & $\begin{array}{l}\text { Retrospective: } \\
\text { osteoarticular infection } \\
\text { (OM, PJl, septic } \\
\text { arthritis), infective } \\
\text { endocarditis or other } \\
\text { bloodstream infection } \\
70 \text { dal and } 145 \text { ST }\end{array}$ & $\begin{array}{l}\text { Not specified for the infective } \\
\text { endocarditis group (all patients } \\
\text { in the dal group received prior } \\
\text { antibiotics during the } \\
\text { hospitalization preceding } \\
\text { definite dal therapy) }\end{array}$ & $\begin{array}{l}\text { Varying: the most frequent } \\
\text { (34\%) was 1,500 mg for } \\
\text { two doses } 1 \text { week apart }\end{array}$ & $\begin{array}{l}\text { Lower rate of } 90 \text {-day } \\
\text { infection-related } \\
\text { readmission in dalbavancin } \\
\text { treated }(17 \%) \text { vs. ST }(28 \%)\end{array}$ & $3 \%$ dal vs. $14 \%$ ST \\
\hline
\end{tabular}

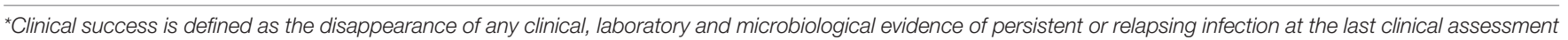

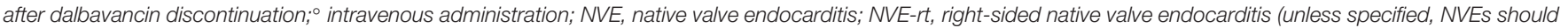

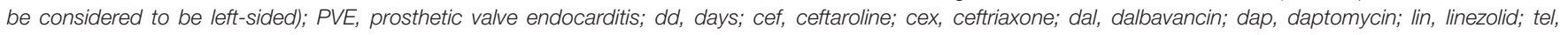

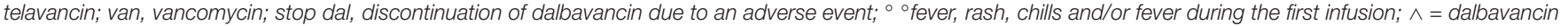

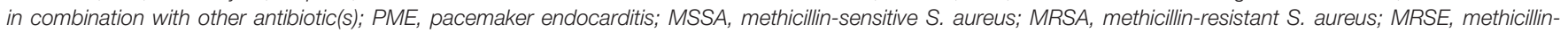

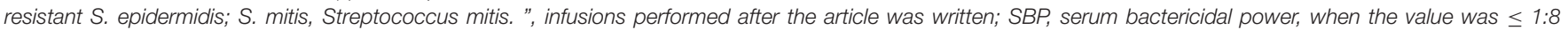
dalbavancin infusion was performed. ${ }^{\S}$ Reported in the article: note of the author (MV) who followed up the case.

cell wall synthesis by binding to the terminal D-alanyl-Dalanine terminus of pentapeptide peptidoglycan precursors, resulting in bactericidal activity against most Gram-positive microorganisms. Notably, recent data showed that dalbavancin $\mathrm{MIC}_{90}$ values remained unchanged, being $\leq 0.06 \mu \mathrm{g} / \mathrm{mL}$ against different species of Gram-positive germs, with overall 
low values: Staphylococcus aureus (MIC50/90 $0.03 \mathrm{mg} / \mathrm{L}$ for both MSSA and MRSA), vancomycin-susceptible Enterococcus faecalis (MIC50/90, 0.03/0.06 mg/L), $\beta$-hemolytic streptococci (MIC50/90, 0.008/0.015 mg/L), and Streptococcus anginosus group (MIC50/90, $\leq 0.004 / \leq 0.004 \mathrm{mg} / \mathrm{L}$ ) (Jones et al., 2013). Interestingly, dalbavancin resistance during or immediately after the antibiotic treatment was evidenced in only two cases (Kussmann et al., 2018; Werth et al., 2018), with the hypothesized mechanisms underlying the reduced susceptibility being linked to an increase in cell-wall thickness (Kussmann et al., 2018). From a clinical point of view, dalbavancin has been approved for use as a 2 -dose regimen (1,000 $\mathrm{mg}$ IV on day 1 and $500 \mathrm{mg}$ IV on day 8 ) or 1 -dose regimen $(1,500 \mathrm{mg} \mathrm{IV})$ for the treatment of ABSSSI, with an efficacy equal to and fewer adverse reactions than the standard treatment with vancomycin followed by oral linezolid (Soriano et al., 2020). Besides being a good choice in managing SSTI, dalbavancin may represent a valuable option for other invasive Gram-positive infections requiring prolonged intravenous treatments, including osteomyelitis, PJI, infective endocarditis, and catheter-related bacteremia (David et al., 2017). Retrospective analyses of patients with these types of infections being treated with dalbavancin showed a favorable outcome in most cases and an excellent safety profile (Tables 2, 3). The efficacy of dalbavancin was also proved in vulnerable patients with osteomyelitis or non-complicated bacteremia where the first-line antimicrobial therapy failed (Bork et al., 2019). Subsequent successful use of dalbavancin in patients with infective endocarditis was also reported (Tobudic et al., 2018). Since endocarditis or MDIs are at high risk of biofilm development, it has been speculated that dalbavancin efficacy in such patients may be linked to a direct mechanism on biofilm eradication. Different studies evaluated the in vitro activity of dalbavancin against biofilms formed by Gram-positive infections. In in vitro biofilm models of Gram-positive cocci, dalbavancin inhibited biofilm formation at low concentrations in a broad number of $S$. aureus, $S$. epidermidis, and enterococci (Fernández et al., 2016; Neudorfer et al., 2018). These values were lower than those observed for other agents such as vancomycin and daptomycin. An exception was represented by vancomycinresistant strains, which showed very high minimum biofilm bactericidal concentrations for all tested agents, including dalbavancin (Fernández et al., 2016; Neudorfer et al., 2018). A recent study evaluated the time-kill kinetics of dalbavancin against biofilm formed by $S$. aureus and coagulase-negative staphylococci (CoNS) (Di Pilato et al., 2020). Dalbavancin and vancomycin, used at a concentration achievable in vivo in bone tissue $(1,4$, and $16 \mu \mathrm{g} / \mathrm{mL})$ for 7 days, showed concentration and time-dependent activities against all tested strains. Besides, dalbavancin showed a greater reduction of biofilm-embedded bacteria in most strains studied, especially at $4 \mu \mathrm{g} / \mathrm{mL}$ and $16 \mu \mathrm{g} / \mathrm{mL}$. In biofilms formed on titanium and cobalt chrome disks, dalbavancin was more active than vancomycin at medium concentrations $(4 \mu \mathrm{g} / \mathrm{mL})$, which are easily reached in bone tissue (Dunne et al., 2015). The activity of dalbavancin against $S$. aureus and S. epidermidis biofilms was compared to other antimicrobials (linezolid, rifampicin, vancomycin, cloxacillin). Notably, the minimal biofilm inhibitory concentration (MBIC) of dalbavancin ranged from 0.5 to $2 \mu \mathrm{g} / \mathrm{mL}$, and in combination with rifampicin, showed the highest biofilm inhibitory effect. In addition, dalbavancin was able to eradicate 6-9-h old biofilms at concentrations of $8-32 \mu \mathrm{g} / \mathrm{mL}$. The other antimicrobials showed no activity against biofilms formed by $S$. aureus. Dalbavancin was effective against $S$. epidermidis biofilm; however, cloxacillin plus rifampicin showed lower MBIC values (Žiemytè et al., 2020). A recent study analyzing the effect of different antibiotics on biofilm-producing MRSA strains from patients with SSTI showed that dalbavancin was 16 and 8 times more active than linezolid and vancomycin, respectively, with an $\mathrm{MBIC}_{90}$ of $0.5 \mu \mathrm{g} / \mathrm{mL}$ (range 0.12-0.5 mg/L) (Sivori et al., 2021).

A few in vivo experimental models evaluated dalbavancin activity in biofilm prevention and treatment. Darouiche and Mansouri evaluated biofilm prevention in a rabbit model inoculated with $S$. aureus and treated with either dalbavancin or vancomycin (Darouiche and Mansouri, 2005). The percentage of colonized devices was comparable in the vancomycin and control group (47\%). In contrast, the dalbavancin group showed a lower trend in device colonization (28\%), although not statistically significant (Darouiche and Mansouri, 2005). Nevertheless, the rate of foreign body contamination in rabbits receiving placebo was around 50\% (lower than other animal models), thus questioning the validity of the model and its discriminatory power for assessing the efficacy of antimicrobials. In 2013, Baldoni et al. tested dalbavancin activity, alone and in combination with rifampicin, on MRSA biofilm in an animal model of tissue-cage infection. Dalbavancin did not show antagonist or synergistic activity with rifampicin; however, when used in combination with rifampicin, it was able to eradicate the biofilm and achieve cure rates of 25$36 \%$ compared to monotherapy. In addition, dalbavancin prevented the insurgence of rifampicin resistance (Baldoni et al., 2013). A more recent paper by Silva et al. (2020) evaluated dalbavancin activity in a rat model of implantassociated orthopedic infection by MRSA. Efficacy was assessed at 7 and 14 days after dalbavancin administration, showing a significant reduction in bacterial colonies on bone tissue and implant.

However, some limitations from these pre-clinical reports should be highlighted: the dosages of dalbavancin in some of the in vivo models may have provided lower antibiotic exposure compared to human pharmacokinetics; the chosen animal models may not represent the ideal in vivo condition for biofilm growth; more data on the combination therapies, especially with rifampicin, would be essential to fully understand the possible role of dalbavancin in hard-to-treat infections.

Furthermore, the clinical evidence available so far derives mostly from retrospective observational studies or case reports (Tables 2,3 ). The only prospective randomized study comparing dalbavancin with the standard of care included patients with osteomyelitis, a condition that is associated with biofilm but that does not involve a foreign body (Rappo et al., 2018). Therefore, based on these promising but still preliminary data, additional prospective randomized trials evaluating the role of dalbavancin in patients with implant-associated infections are strongly encouraged. 


\section{CONCLUSION}

With an aging population and the resulting increase in diseases such as cancer and diabetes, together with the development of new implantable medical devices, there is an increasingly growing incidence of chronic infections typically associated with biofilm formation.

The current management of several biofilm-related Grampositive infections requires prolonged antibiotic therapy and, in the majority of the cases, the complete removal of the implant.

Amongst the available antimicrobials with different degrees of activity against biofilm, dalbavancin seems to provide effective therapy in a significant proportion of cases due to its ultralong activity and effectiveness in the setting of MDIs with a relatively low number of adverse effects. Furthermore, its ease of administration allows to accelerate patients' discharge from hospital and increase patients' compliance to the

\section{REFERENCES}

Abad, L., Josse, J., Tasse, J., Lustig, S., Ferry, T., Diot, A., et al. (2020). Antibiofilm and intraosteoblastic activities of rifamycins against Staphylococcus aureus: promising in vitro profile of rifabutin. J. Antimicrob. Chemother. 75, 1466-1473. doi: 10.1093/jac/dkaa061

Agarwal, A., Kelkar, A., Agarwal, A. G., Jayaswal, D., Schultz, C., Jayaswal, A., et al. (2020). Implant Retention or Removal for Management of Surgical Site Infection After Spinal Surgery. Global Spine J. 10, 640-646. doi: 10.1177/ 2192568219869330

Albano, M., Karau, M. J., Greenwood-Quaintance, K. E., Osmon, D. R., Oravec, C. P., Berry, D. J., et al. (2019). In Vitro Activity of Rifampin, Rifabutin, Rifapentine, and Rifaximin against Planktonic and Biofilm States of Staphylococci Isolated from Periprosthetic Joint Infection. Antimicrob. Agents Chemother. 63, e00959-19. doi: 10.1128/AAC.00959-19

Almangour, T. A., and Alhifany, A. A. (2020). Dalbavancin for the management of osteomyelitis: a major step forward? J. Antimicrob. Chemother. 75, 2717-2722. doi: 10.1093/jac/dkaa188

Almangour, T. A., Fletcher, V., Alessa, M., Alhifany, A. A., and Tabb, D. (2017). Multiple Weekly Dalbavancin Dosing for the Treatment of Native Vertebral Osteomyelitis Caused by Methicillin-Resistant Staphylococcus Aureus: a Case Report. Am. J. Case Rep. 18, 1315-1319. doi: 10.12659/ajcr.905930

Almangour, T. A., Perry, G. K., Terriff, C. M., Alhifany, A. A., and Kaye, K. S. (2019). Dalbavancin for the management of gram-positive osteomyelitis: effectiveness and potential utility. Diagn. Microbiol. Infect. Dis. 93, 213-218. doi: 10.1016/j.diagmicrobio.2018.10.007

Arrieta-Loitegui, M., Caro-Teller, J. M., Ortiz-Pérez, S., López-Medrano, F., San Juan-Garrido, R., and Ferrari-Piquero, J. M. (2020). Effectiveness, safety and cost analysis of dalbavancin in clinical practice. Eur. J. Hosp. Pharm. doi: 10. 1136/ejhpharm-2020-002315 [Epub Online ahead of print].

Baldoni, D., Furustrand Tafin, U., Aeppli, S., Angevaare, E., Oliva, A., Haschke, M., et al. (2013). Activity of dalbavancin, alone and in combination with rifampicin, against methicillin-resistant Staphylococcus aureus in a foreign-body infection model. Int. J. Antimicrob. Agents 42, 220-225. doi: 10.1016/j.ijantimicag.2013. 05.019

Bartoletti, M., Mikus, E., Pascale, R., Giannella, M., Tedeschi, S., Calvi, S., et al. (2019). Clinical experience with dalbavancin for the treatment of deep sternal wound infection. J. Glob. Antimicrob. Resist. 18, 195-198. doi: 10.1016/j.jgar. 2019.03.015

Berne, C., Ellison, C. K., Ducret, A., and Brun, Y. V. (2018). Bacterial adhesion at the single-cell level. Nat. Rev. Microbiol. 16, 616-627. doi: 10.1038/s41579-0180057-5

Blomström-Lundqvist, C., Traykov, V., Erba, P. A., Burri, H., Nielsen, J. C., Bongiorni, M. G., et al. (2020). European Heart Rhythm Association (EHRA) international consensus document on how to prevent, diagnose, and treat therapy, thus reducing both healthcare costs and the risks of developing multidrug-resistant bacterial infections due to prolonged hospital stay.

\section{AUTHOR CONTRIBUTIONS}

All authors designed the study, wrote the manuscript, interpreted the clinical data, contributed to the article, and approved the submitted version.

\section{ACKNOWLEDGMENTS}

We sincerely thank Mirella Biava for her expertise and assistance throughout all aspects of our study and for the help in writing the manuscript.

cardiac implantable electronic device infections-endorsed by the Heart Rhythm Society (HRS), the Asia Pacific Heart Rhythm Society (APHRS), the Latin American Heart Rhythm Society (LAHRS), International Society for Cardiovascular Infectious Diseases (ISCVID) and the European Society of Clinical Microbiology and Infectious Diseases (ESCMID) in collaboration with the European Association for Cardio-Thoracic Surgery (EACTS). Europace 22, 515-549. doi: 10.1093/europace/euz246

Bork, J. T., Heil, E. L., Berry, S., Lopes, E., Davé, R., Gilliam, B. L., et al. (2019). Dalbavancin Use in Vulnerable Patients Receiving Outpatient Parenteral Antibiotic Therapy for Invasive Gram-Positive Infections. Infect. Dis. Ther. 8, 171-184. doi: 10.1007/s40121-019-0247-0

Boucher, H. W., Wilcox, M., Talbot, G. H., Puttagunta, S., Das, A. F., Dunne, M. W., et al. (2014). Once-weekly dalbavancin versus daily conventional therapy for skin infection. N. Engl. J. Med. 370, 2169-2179. doi: 10.1056/NEJMoa1310480

Bouza, E., Valerio, M., Soriano, A., Morata, L., Carus, E. G., Rodríguez-González, C., et al. (2018). Dalbavancin in the treatment of different gram-positive infections: a real-life experience. Int. J. Antimicrob. Agents 51, 571-577. doi: 10.1016/j.ijantimicag.2017.11.008

Bryson-Cahn, C., Beieler, A. M., Chan, J. D., Harrington, R. D., and Dhanireddy, S. (2019). Dalbavancin as Secondary Therapy for Serious Staphylococcus aureus Infections in a Vulnerable Patient Population. Open Forum Infect. Dis. 6:ofz028. doi: 10.1093/ofid/ofz028

Buke, C., Armand-Lefevre, L., Lolom, I., Guerinot, W., Deblangy, C., Ruimy, R., et al. (2007). Epidemiology of multidrug-resistant bacteria in patients with long hospital stays. Infect. Control Hosp. Epidemiol. 28, 1255-1260. doi: 10.1086/ 522678

Ch'ng, J. H., Chong, K. K. L., Lam, L. N., Wong, J. J., and Kline, K. A. (2019). Biofilm-associated infection by enterococci. Nat. Rev. Microbiol. 17, 82-94. doi: 10.1038/s41579-018-0107-z

Ciofu, O., Rojo-Molinero, E., Macià, M. D., and Oliver, A. (2017). Antibiotic treatment of biofilm infections. APMIS 125, 304-319. doi: 10.1111/apm.12673

da Silva, R. A. G., Afonina, I., and Kline, K. A. (2021). Eradicating biofilm infections: an update on current and prospective approaches. Curr. Opin. Microbiol. 63, 117-125. doi: 10.1016/j.mib.2021.07.001

Darouiche, R. O., Dhir, A., Miller, A. J., Landon, G. C., Raad, I. I., and Musher, D. M. (1994). Vancomycin penetration into biofilm covering infected prostheses and effect on bacteria. J. Infect. Dis. 170, 720-723. doi: 10.1093/infdis/170. 3.720

Darouiche, R. O., and Mansouri, M. D. (2005). Dalbavancin compared with vancomycin for prevention of Staphylococcus aureus colonization of devices in vivo. J. Infect. 50, 206-209. doi: 10.1016/j.jinf.2004.05.006

Darouiche, R. O., Raad, I. I., Heard, S. O., Thornby, J. I., Wenker, O. C., Gabrielli, A., et al. (1999). A comparison of two antimicrobial-impregnated central venous catheters. Catheter Study Group. N. Engl. J. Med. 7, 1-8. doi: 10.1056/ NEJM199901073400101 
David, M. Z., Dryden, M., Gottlieb, T., Tattevin, P., and Gould, I. M. (2017). Recently approved antibacterials for methicillin-resistant Staphylococcus aureus (MRSA) and other Gram-positive pathogens: the shock of the new. Int. J. Antimicrob. Agents 50, 303-307. doi: 10.1016/j.ijantimicag.2017.05.006

Del Pozo, J. L., and Patel, R. (2009). Clinical practice. Infection associated with prosthetic joints. N. Engl. J. Med. 361, 787-794. doi: 10.1056/NEJMcp0905029

Di Domenico, E. G., Rimoldi, S. G., Cavallo, I., D'Agosto, G., Trento, E., Cagnoni, G., et al. (2019). Microbial biofilm correlates with an increased antibiotic tolerance and poor therapeutic outcome in infective endocarditis. BMC Microbiol. 19:228. doi: 10.1186/s12866-019-1596-2

Di Pilato, V., Ceccherini, F., Sennati, S., D’Agostino, F., Arena, F., D’Atanasio, N., et al. (2020). In vitro time-kill kinetics of dalbavancin against Staphylococcus spp. biofilms over prolonged exposure times. Diagn. Microbiol. Infect. Dis. 96:114901. doi: 10.1016/j.diagmicrobio.2019.114901

Dinh, A., Duran, C., Pavese, P., Khatchatourian, L., Monnin, B., Bleibtreu, A., et al. (2019). French national cohort of first use of dalbavancin: a high proportion of off-label use. Int. J. Antimicrob. Agents 54, 668-672. doi: 10.1016/j.ijantimicag. 2019.08.006

Doroshenko, N., Tseng, B. S., Howlin, R. P., Deacon, J., Wharton, J. A., Thurner, P. J., et al. (2014). Extracellular DNA impedes the transport of vancomycin in Staphylococcus epidermidis biofilms preexposed to subinhibitory concentrations of vancomycin. Antimicrob. Agents Chemother. 58, 7273-7282. doi: 10.1128/AAC.03132-14

Dunne, M. W., Puttagunta, S., Giordano, P., Krievins, D., Zelasky, M., and Baldassarre, J. (2016). A Randomized Clinical Trial of Single-Dose Versus Weekly Dalbavancin for Treatment of Acute Bacterial Skin and Skin Structure Infection. Clin. Infect. Dis. 62, 545-551. doi: 10.1093/cid/civ982

Dunne, M. W., Puttagunta, S., Sprenger, C. R., Rubino, C., Van Wart, S., and Baldassarre, J. (2015). Extended-duration dosing and distribution of dalbavancin into bone and articular tissue. Antimicrob. Agents Chemother. 59, 1849-1855. doi: 10.1128/AAC.04550- 14

Fabretti, F., Theilacker, C., Baldassarri, L., Kaczynski, Z., Kropec, A., Holst, O., et al. (2006). Alanine esters of enterococcal lipoteichoic acid play a role in biofilm formation and resistance to antimicrobial peptides. Infect Immun. 74, 4164-4171. doi: 10.1128/IAI.00111-06

Fernández, J., Greenwood-Quaintance, K. E., and Patel, R. (2016). In vitro activity of dalbavancin against biofilms of staphylococci isolated from prosthetic joint infections. Diagn. Microbiol. Infect. Dis. 85, 449-451. doi: 10.1016/j. diagmicrobio.2016.05.009

Foster, T. J. (2019). The MSCRAMM Family of Cell-Wall-Anchored Surface Proteins of Gram-Positive Cocci. Trends Microbiol. 27, 927-941. doi: 10.1016/j. tim.2019.06.007

Furustrand Tafin, U., Corvec, S., Betrisey, B., Zimmerli, W., and Trampuz, A. (2012). Role of rifampin against Propionibacterium acnes biofilm in vitro and in an experimental foreign-body infection model. Antimicrob. Agents Chemother. 56, 1885-1891. doi: 10.1128/AAC.05552-11

Gellert, M., Hardt, S., Köder, K., Renz, N., Perka, C., and Trampuz, A. (2020). Biofilm-active antibiotic treatment improves the outcome of knee periprosthetic joint infection: results from a 6-year prospective cohort study. Int. J. Antimicrob. Agents 55:105904. doi: 10.1016/j.ijantimicag.2020.10 5904

Guzman Prieto, A. M., van Schaik, W., Rogers, M. R., Coque, T. M., Baquero, F., Corander, J., et al. (2016). Global Emergence and Dissemination of Enterococci as Nosocomial Pathogens: attack of the Clones? Front. Microbiol. 7:788. doi: 10.3389/fmicb.2016.00788

Hancock, L. E., and Perego, M. (2004). Systematic inactivation and phenotypic characterization of two-component signal transduction systems of Enterococcus faecalis V583. J. Bacteriol. 186, 7951-7958. doi: 10.1128/JB.186.23.7951-7958.2004

Henry-Stanley, M. J., Hess, D. J., and Wells, C. L. (2014). Aminoglycoside inhibition of Staphylococcus aureus biofilm formation is nutrient dependent. J. Med. Microbiol. 63, 861-869. doi: 10.1099/jmm.0.068130-0

Hidalgo-Tenorio, C., Vinuesa, D., Plata, A., Martin Dávila, P., Iftimie, S., Sequera, S., et al. (2019). DALBACEN cohort: dalbavancin as consolidation therapy in patients with endocarditis and/or bloodstream infection produced by grampositive cocci. Ann. Clin. Microbiol. Antimicrob. 18:30. doi: 10.1186/s12941019-0329-6
Høiby, N., Bjarnsholt, T., Moser, C., Bassi, G. L., Coenye, T., Donelli, G., et al. (2015). ESCMID guideline for the diagnosis and treatment of biofilm infections 2014. Clin. Microbiol. Infect. 21, S1-S25. doi: 10.1016/j.cmi.2014. 10.024

Huang, L., Zhang, R., Hu, Y., Zhou, H., Cao, J., Lv, H., et al. (2019). Epidemiology and risk factors of methicillin-resistant Staphylococcus aureus and vancomycinresistant enterococci infections in Zhejiang China from 2015 to 2017. Antimicrob. Resist. Infect. Control 8:90. doi: 10.1186/s13756-019-0539-x

Izakovicova, P., Borens, O., and Trampuz, A. (2019). Periprosthetic joint infection: current concepts and outlook. EFORT Open Rev. 4, 482-494. doi: 10.1302/20585241.4.180092

Jo, A., and Ahn, J. (2016). Phenotypic and genotypic characterisation of multiple antibiotic-resistant Staphylococcus aureus exposed to subinhibitory levels of oxacillin and levofloxacin. BMC Microbiol. 16:170. doi: 10.1186/s12866-0160791-7

Jones, R. N., Flamm, R. K., and Sader, H. S. (2013). Surveillance of dalbavancin potency and spectrum in the United States (2012). Diagn. Microbiol. Infect. Dis. 76, 122-123. doi: 10.1016/j.diagmicrobio.2013.01.003

Justo, J. A., and Bookstaver, P. B. (2014). Antibiotic lock therapy: review of technique and logistical challenges. Infect. Drug Resist. 7, 343-363. doi: 10.2147/ IDR.S51388

Karygianni, L., Ren, Z., Koo, H., and Thurnheer, T. (2020). Biofilm Matrixome: extracellular Components in Structured Microbial Communities. Trends Microbiol. 28, 668-681. doi: 10.1016/j.tim.2020.03.016

Katsikogianni, M., and Missirlis, Y. F. (2004). Concise review of mechanisms of bacterial adhesion to biomaterials and of techniques used in estimating bacteria-material interactions. Eur. Cell Mater. 8, 37-57. doi: 10.22203/ecm. v008a05

Kaye, K. S., Petty, L. A., Shorr, A. F., and Zilberberg, M. D. (2019). Current Epidemiology, Etiology, and Burden of Acute Skin Infections in the United States. Clin. Infect. Dis. 68, S193-S199. doi: 10.1093/cid/ciz002

Knafl, D., Tobudic, S., Cheng, S. C., Bellamy, D. R., and Thalhammer, F. (2017). Dalbavancin reduces biofilms of methicillin-resistant Staphylococcus aureus (MRSA) and methicillin-resistant Staphylococcus epidermidis (MRSE). Eur. J. Clin. Microbiol. Infect. Dis. 36, 677-680. doi: 10.1007/s10096-016-2845-Z

Köder, K., Hardt, S., Gellert, M. S., Haupenthal, J., Renz, N., Putzier, M., et al. (2020). Outcome of spinal implant-associated infections treated with or without biofilm-active antibiotics: results from a 10-year cohort study. Infection 48, 559-568. doi: 10.1007/s15010-020-01435-2

Kussmann, M., Karer, M., Obermueller, M., Schmidt, K., Barousch, W., Moser, D., et al. (2018). Emergence of a dalbavancin induced glycopeptide/lipoglycopeptide non-susceptible Staphylococcus aureus during treatment of a cardiac device-related endocarditis. Emerg. Microbes Infect. 7:202. doi: 10.1038/s41426-018-0205-z

Landini, G., Riccobono, E., Giani, T., Arena, F., Rossolini, G. M., and Pallecchi, L. (2015). Bactericidal activity of ceftaroline against mature Staphylococcus aureus biofilms. Int. J. Antimicrob. Agents 45, 551-553. doi: 10.1016/j.ijantimicag.2015. 01.001

Lázaro-Díez, M., Remuzgo-Martínez, S., Rodríguez-Mirones, C., Acosta, F., Icardo, J. M., Martínez-Martínez, L., et al. (2016). Effects of Subinhibitory Concentrations of Ceftaroline on Methicillin-Resistant Staphylococcus aureus (MRSA) Biofilms. PLoS One 11:e0147569. doi: 10.1371/journal.pone.0147569

Lebeaux, D., Ghigo, J. M., and Beloin, C. (2014). Biofilm-related infections: bridging the gap between clinical management and fundamental aspects of recalcitrance toward antibiotics. Microbiol. Mol. Biol. Rev. 78, 510-543.

Leite, B., Gomes, F., Teixeira, P., Souza, C., Pizzolitto, E., and Oliveira, R. (2011). In vitro activity of daptomycin, linezolid and rifampicin on Staphylococcus epidermidis biofilms. Curr. Microbiol. 63, 313-317. doi: 10.1007/s00284-0119980-7

Lister, J. L., and Horswill, A. R. (2014). Staphylococcus aureus biofilms: recent developments in biofilm dispersal. Front. Cell. Infect. Microbiol. 4:178. doi: 10.3389/fcimb.2014.00178

Loupa, C. V., Lykoudi, E., Meimeti, E., Moisoglou, I., Voyatzoglou, E. D., Kalantzi, S., et al. (2020). Successful Treatment of Diabetic Foot Osteomyelitis with Dalbavancin. Med. Arch. 74, 243-245. doi: 10.5455/medarh.2020.74.243-245

Masters, E. A., Trombetta, R. P., de Mesy Bentley, K. L., Boyce, B. F., Gill, A. L., Gill, S. R., et al. (2019). Evolving concepts in bone infection: redefining "biofilm", 
"acute vs. chronic osteomyelitis", "the immune proteome" and "local antibiotic therapy". Bone Res. 7:20. doi: 10.1038/s41413-019-0061-z

Matt, M., Duran, C., Courjon, J., Lotte, R., Moing, V. L., Monnin, B., et al. (2021). Dalbavancin treatment for prosthetic joint infections in real-life: a national cohort study and literature review. J. Glob. Antimicrob. Resist. 25, 341-345. doi: 10.1016/j.jgar.2021.03.026

McCarthy, H., Rudkin, J. K., Black, N. S., Gallagher, L., O’Neill, E., and O'Gara, J. P. (2015). Methicillin resistance and the biofilm phenotype in Staphylococcus aureus. Front. Cell. Infect. Microbiol. 5:1. doi: 10.3389/fcimb.2015.00001

Mihailescu, R., Furustrand Tafin, U., Corvec, S., Oliva, A., Betrisey, B., Borens, O., et al. (2014). High activity of Fosfomycin and Rifampin against methicillinresistant staphylococcus aureus biofilm in vitro and in an experimental foreignbody infection model. Antimicrob. Agents Chemother. 58, 2547-2553. doi: 10. 1128/AAC.02420-12

Morata, L., Cobo, J., Fernández-Sampedro, M., Guisado Vasco, P., Ruano, E., LoraTamayo, J., et al. (2019). Safety and Efficacy of Prolonged Use of Dalbavancin in Bone and Joint Infections. Antimicrob. Agents Chemother. 63, e02280-18. doi: 10.1128/AAC.02280- 18

Morrisette, T., Miller, M. A., Montague, B. T., Barber, G. R., McQueen, R. B., and Krsak, M. (2019). On- and off-label utilization of dalbavancin and oritavancin for Gram-positive infections. J. Antimicrob. Chemother. 74, 2405-2416. doi: 10.1093/jac/dkz162

Navarro-Jiménez, G., Fuentes-Santos, C., Moreno-Núñez, L., Alfayate-García, J., Campelo-Gutierrez, C., and Sanz-Márquez, S. (2021). Experience in the use of dalbavancin in diabetic foot infection. Enferm. Infecc. Microbiol. Clin. doi: 10.1016/j.eimc.2020.11.013 [Epub Online ahead of print].

Neoh, K. G., Li, M., Kang, E. T., Chiong, E., and Tambyah, P. A. (2017). Surface modification strategies for combating catheter-related complications: recent advances and challenges. J. Mater. Chem. B 5, 2045-2067. doi: 10.1039/ c6tb03280j

Neudorfer, K., Schmidt-Malan, S. M., and Patel, R. (2018). Dalbavancin is active in vitro against biofilms formed by dalbavancin-susceptible enterococci. Diagn. Microbiol. Infect. Dis. 90, 58-63. doi: 10.1016/j.diagmicrobio.2017.09.015

Nguyen, H. T. T., Nguyen, T. H., and Otto, M. (2020). The staphylococcal exopolysaccharide PIA - Biosynthesis and role in biofilm formation, colonization, and infection. Comput. Struct. Biotechnol. J. 18, 3324-3334. doi: 10.1016/j.csbj.2020.10.027

Oliva, A., Furustrand Tafin, U., Maiolo, E. M., Jeddari, S., Bétrisey, B., and Trampuz, A. (2014). Activities of fosfomycin and rifampin on planktonic and adherent Enterococcus faecalis strains in an experimental foreign-body infection model. Antimicrob. Agents Chemother. 58, 1284-1293. doi: 10.1128/ AAC.02583-12

Otto, M. (2018). Staphylococcal Biofilms. Microbiol. Spectr. 6:6.4.27. doi: 10.1128/ microbiolspec.GPP3-0023-2018

Palmer, J., Flint, S., and Brooks, J. (2007). Bacterial cell attachment, the beginning of a biofilm. J. Ind. Microbiol. Biotechnol. 34, 577-588. doi: 10.1007/s10295-007$0234-4$

Parra-Ruiz, J., Bravo-Molina, A., Peña-Monje, A., and Hernández-Quero, J. (2012). Activity of linezolid and high-dose daptomycin, alone or in combination, in an in vitro model of Staphylococcus aureus biofilm. J. Antimicrob. Chemother. 67, 2682-2685. doi: 10.1093/jac/dks272

Pavoni, G. L., Falcone, M., Baiocchi, P., Tarasi, A., Cassone, M., Serra, P., et al. (2002). Conservative medical therapy of infections following osteosynthesis: a retrospective analysis of a six-year experience. J. Chemother. 14, 378-383. doi: 10.1179/joc.2002.14.4.378

Pavoni, G. L., Giannella, M., Falcone, M., Scorzolini, L., Liberatore, M., Carlesimo, B., et al. (2004). Conservative medical therapy of prosthetic joint infections: retrospective analysis of an 8-year experience. Clin. Microbiol. Infect. 10, 831837. doi: 10.1111/j.1469-0691.2004.00928.x

Peacock, J. E. Jr., Stafford, J. M., Le, K., Sohail, M. R., Baddour, L. M., Prutkin, J. M., et al. (2018). Attempted salvage of infected cardiovascular implantable electronic devices: are there clinical factors that predict success? Pacing Clin. Electrophysiol. 41, 524-531. doi: 10.1111/pace.13319

Qu, G. X., Zhang, C. H., Yan, S. G., and Cai, X. Z. (2019). Debridement, antibiotics, and implant retention for periprosthetic knee infections: a pooling analysis of 1266 cases. J. Orthop. Surg. Res. 14:358. doi: 10.1186/s13018-019-1378-4

Rappo, U., Puttagunta, S., Shevchenko, V., Shevchenko, A., Jandourek, A., Gonzalez, P. L., et al. (2018). Dalbavancin for the Treatment of Osteomyelitis in
Adult Patients: a Randomized Clinical Trial of Efficacy and Safety. Open Forum Infect. Dis. 6:ofy331. doi: 10.1093/ofid/ofy331

Römling, U., and Balsalobre, C. (2012). Biofilm infections, their resilience to therapy and innovative treatment strategies. J. Intern. Med. 272, 541-561. doi: 10.1111/joim.12004

Rumbaugh, K. P., and Sauer, K. (2020). Biofilm dispersion. Nat. Rev. Microbiol. 18, 571-586. doi: 10.1038/s41579-020-0385-0

Sava, I. G., Heikens, E., and Huebner, J. (2010). Pathogenesis and immunity in enterococcal infections. Clin. Microbiol. Infect. 16, 533-540. doi: 10.1111/j. 1469-0691.2010.03213.x

Seebach, E., and Kubatzky, K. F. (2019). Chronic Implant-Related Bone InfectionsCan Immune Modulation be a Therapeutic Strategy? Front. Immunol. 10:1724. doi: 10.3389/fimmu.2019.01724

Segreti, J., Nelson, J. A., and Trenholme, G. M. (1998). Prolonged suppressive antibiotic therapy for infected orthopedic prostheses. Clin. Infect. Dis. 27, 711-713. doi: $10.1086 / 514951$

Sharma, D., Misba, L., and Khan, A. U. (2019). Antibiotics versus biofilm: an emerging battleground in microbial communities. Antimicrob. Resist. Infect. Control 8:76. doi: 10.1186/s13756-019-0533-3

Silva, V., Antão, H. S., Guimarães, J., Prada, J., Pires, I., Martins, Â, et al. (2020). Efficacy of dalbavancin against MRSA biofilms in a rat model of orthopaedic implant-associated infection. J. Antimicrob. Chemother. 75, 2182-2187. doi: 10.1093/jac/dkaa163

Sivori, F., Cavallo, I., Ensoli, F., and Di Domenico, E. G. (2021). Dalbavancin activity against biofilm-growing MRSA isolated from patients with complicated skin and soft tissue infections. Eur Congr. Clin. Microbiol. Infect. Dis. 2975:24

Soriano, A., Rossolini, G. M., and Pea, F. (2020). The role of dalbavancin in the treatment of acute bacterial skin and skin structure infections (ABSSSIs). Expert Rev. Anti Infect. Ther. 18, 415-422. doi: 10.1080/14787210.2020.174 6643

Spaziante, M., Franchi, C., Taliani, G., D’Avolio, A., Pietropaolo, V., Biliotti, E., et al. (2019). Serum Bactericidal Activity Levels Monitor to Guide Intravenous Dalbavancin Chronic Suppressive Therapy of Inoperable Staphylococcal Prosthetic Valve Endocarditis: a Case Report. Open Forum Infect. Dis. 6:ofz427. doi: 10.1093/ofid/ofz427

Steele, J. M., Seabury, R. W., Hale, C. M., and Mogle, B. T. (2018). Unsuccessful treatment of methicillin-resistant Staphylococcus aureus endocarditis with dalbavancin. J. Clin. Pharm. Ther. 43, 101-103. doi: 10.1111/jcpt.12580

Streifel, A. C., Sikka, M. K., Bowen, C. D., and Lewis, J. S. II (2019). Dalbavancin use in an academic medical centre and associated cost savings. Int. J. Antimicrob. Agents 54, 652-654. doi: 10.1016/j.ijantimicag.2019.08.007

Tang, H. J., Chen, C. C., Cheng, K. C., Toh, H. S., Su, B. A., Chiang, S. R., et al. (2012). In vitro efficacy of fosfomycin-containing regimens against methicillinresistant Staphylococcus aureus in biofilms. J. Antimicrob. Chemother. 67, 944-950. doi: 10.1093/jac/dkr535

Tang, H. J., Chen, C. C., Cheng, K. C., Wu, K. Y., Lin, Y. C., Zhang, C. C., et al. (2013). In vitro efficacies and resistance profiles of rifampin-based combination regimens for biofilm-embedded methicillin-resistant Staphylococcus aureus. Antimicrob. Agents Chemother. 57, 5717-5720. doi: 10.1128/AAC.01236-13

Tobudic, S., Forstner, C., Burgmann, H., Lagler, H., Ramharter, M., Steininger, C., et al. (2018). Dalbavancin as Primary and Sequential Treatment for GramPositive Infective Endocarditis: 2-Year Experience at the General Hospital of Vienna. Clin. Infect. Dis. 67, 795-798. doi: 10.1093/cid/ciy279

Tong, S. Y., Davis, J. S., Eichenberger, E., Holland, T. L., and Fowler, V. G. Jr. (2015). Staphylococcus aureus infections: epidemiology, pathophysiology, clinical manifestations, and management. Clin. Microbiol. Rev. 28, 603-661. doi: 10.1128/CMR.00134-14

Veve, M. P., Patel, N., Smith, Z. A., Yeager, S. D., Wright, L. R., and Shorman, M. A. (2020). Comparison of dalbavancin to standard-of-care for outpatient treatment of invasive Gram-positive infections. Int. J. Antimicrob. Agents 56:106210. doi: 10.1016/j.ijantimicag.2020.106210

Vilchez, H. H., Escudero-Sanchez, R., Fernandez-Sampedro, M., Murillo, O., Auñón, Á, Rodríguez-Pardo, D., et al. (2021). Prosthetic Shoulder Joint Infection by Cutibacterium acnes: does Rifampin Improve Prognosis? A Retrospective, Multicenter, Observational Study. Antibiotics 10:475. doi: 10. 3390/antibiotics 10050475

Werth, B. J., Jain, R., Hahn, A., Cummings, L., Weaver, T., Waalkes, A., et al. (2018). Emergence of dalbavancin non-susceptible, vancomycin-intermediate 
Staphylococcus aureus (VISA) after treatment of MRSA central line-associated bloodstream infection with a dalbavancin- and vancomycin-containing regimen. Clin. Microbiol. Infect. 24, 429.e1-429.e5. doi: 10.1016/j.cmi.2017. 07.028

Wunsch, S., Krause, R., Valentin, T., Prattes, J., Janata, O., Lenger, A., et al. (2019). Multicenter clinical experience of real life Dalbavancin use in gram-positive infections. Int. J. Infect. Dis. 81, 210-214. doi: 10.1016/j.ijid.2019.02.013

Zheng, J. X., Sun, X., Lin, Z. W., Qi, G. B., Tu, H. P., Wu, Y., et al. (2019). In vitro activities of daptomycin combined with fosfomycin or rifampin on planktonic and adherent linezolid-resistant isolates of Enterococcus faecalis. J. Med. Microbiol. 68, 493-502. doi: 10.1099/jmm.0.00094.5

Žiemytė, M., Rodríguez-Díaz, J. C., Ventero, M. P., Mira, A., and Ferrer, M. D. (2020). Effect of dalbavancin on staphylococcal biofilms when administered alone or in combination with biofilm-detaching compounds. Front. Microbiol. 11:553. doi: 10.3389/fmicb.2020.00553

Zimmerli, W., Trampuz, A., and Ochsner, P. E. (2004). Prosthetic-joint infections. N. Engl. J. Med. 351, 1645-1654. doi: 10.1056/NEJMra040181
Conflict of Interest: The authors declare that the research was conducted in the absence of any commercial or financial relationships that could be construed as a potential conflict of interest.

Publisher's Note: All claims expressed in this article are solely those of the authors and do not necessarily represent those of their affiliated organizations, or those of the publisher, the editors and the reviewers. Any product that may be evaluated in this article, or claim that may be made by its manufacturer, is not guaranteed or endorsed by the publisher.

Copyright $\odot 2021$ Oliva, Stefani, Venditti and Di Domenico. This is an openaccess article distributed under the terms of the Creative Commons Attribution License (CC BY). The use, distribution or reproduction in other forums is permitted, provided the original author(s) and the copyright owner(s) are credited and that the original publication in this journal is cited, in accordance with accepted academic practice. No use, distribution or reproduction is permitted which does not comply with these terms. 